UDC 502.171:620.92:332.834.1:64(477)

JEL Classification: D13, E52, G28, Q28, Q42

http://doi.org/10.21272/mmi.2018.4-14

Iryna Sotnyk,

D.SC., Professor, Sumy State University, Ukraine

Iryna Shvets,

D.Sc., Professor, Donetsk National Technical University, Ukraine

Liudmyla Momotiuk,

D.SC., Professor, National Academy of Statistics, Accounting and Audit, Ukraine

Yulija Chortok,

Ph.D., Associate Professor, Sumy State University, Ukraine

\title{
Management of renewable energy innovative development in Ukrainian households: problems of financial support
}

Abstract. The article investigates the current state of management of "green" energy development in the private sector of Ukraine. The mechanisms of economic stimulation, which are used in the countries of the European Union and in Ukraine for the development of the renewable energy sector, are analyzed. On the basis of comparison of domestic and foreign tools revealed the limitation of the economic and financial leverages, which are used in public level in Ukraine to motivate households to implement renewable energy projects as well as the lack of well-established partnership between stakeholders of the real, financial and public sectors. The main stimulus for renewable energy innovative development of the private sector is the feed-in tariff, as well as the simplified procedure for connecting "green" power plants to the general electric grid. Instead, for legal entities additional allowances for the feed-in tariff, tax and other privileges are provided. Taking into consideration the low incomes of Ukrainian households, the authors substantiated the necessity of expanding the range of applicable economic stimulus tools in terms of increasing public financial and credit support for projects on the construction of private renewable energy facilities. In support of this thesis, in the article were made an analysis of the economic feasibility of attracting credit resources to projects on the construction of renewable energy objects in the household sector. Calculations of the net current value and discounted payback periods of projects involving borrowed green loan by Ukrainian and American banks showed that targeted loans provided by Ukrainian banks in their terms do not allow the borrower to return funds at the expense of household income from feed-in tariff. Payback periods of loans far exceed the terms of their provision. The only acceptable option is lending within the framework of the Ukrgazbank Eco-Energy program for 5 years in the amount of $50 \%$ of the initial investment, which implies the application of a preferential credit rate of 0,001\%. Considering the Clean Energy program of the American Savings Bank, within a 10-year lending period, acceptable alternatives are the attraction of credit resources up to $85 \%$ of the volume of required investment, that is, if at least $15 \%$ of the own contribution. Thus, clients of the American bank have more favourable conditions for the implementation of renewable energy projects. In order to increase the investment of the population in green energy facilities, the authors substantiated the directions of strengthening public financial and credit support of green energy projects in the private sector of Ukraine.

Keywords: innovative development, renewable energy, household, the partnership of stakeholders, credit resources, public financial support, management.

Introduction. Renewable energy $(\mathrm{RE})$ is increasingly recognized as a priority of public policy in both developed and developing countries. The reason for this is the inexhaustibility of renewable energy sources (RES), as well as the constant reduction in prices for technologies that enable their use. In addition, the positive environmental effects of RE also make an attractive transition to "green" energy production. For the conditions of Ukraine, which is insufficiently equipped with its own traditional energy resources and has significant potential for the development of the RE, the deployment of "green" power supplies brings a number of benefits. Firstly, it is the achievement of energy independence, and secondly,

Cite as: Sotnyk, I., Shvets, I., Momotiuk, L., \& Chortok, Y. (2018). Management of Renewable Energy Innovative Development in Ukrainian Households: Problems of Financial Support. Marketing and Management of Innovations, 4, 150-160. 
the improvement of the socio-economic situation through the creation of new jobs in the RE sector as well as the expansion of access to energy resources, and thirdly, the resolution of actual environmental problems. As a member of the Energy Community, Ukraine implemented the EU Directive 2009/28/EC on the promotion of RE, and committed to the share of green energy in 2020 in the overall consumption structure would be $11 \%$ (CMU, 2014). According to the Energy Strategy of Ukraine until 2035, this figure should reach $25 \%$ in 2035 (CMU, 2017). However, the actual results of RE's development are threatening to fail to meet the planned targets: in 2017, the share of RES in the energy balance was only $1.47 \%$ (NCSREPU, 2018a), which is almost 7.5 times less than the 2020 target. According to many experts, the slow pace of growth of "green" energy in the country is conditioned by the imperfection of existing economic mechanisms managing and supporting the development of this sector, which causes the involvement of a limited number of economic agents in this activity. First of all, this applies to households that, having the legal right to receive higher revenues from electricity generation from RES, they delay the installation of "green" power plants due to lack of public financial support. The ineffective interaction between stakeholders of various sectors of the economy: public, financial, and real (Masharsky et al, 2018) has a significant negative impact on the development of the private sector of RE. It turns out that the public authorities are not able to respond in a time to the needs of households and offer the population, together with financial and credit institutions, mutually beneficial programs for financing green energy production.

Analysis of main research and publications. The works of many foreign Abolhosseini $\mathrm{S}$. (Abolhosseini \& Heshmati, 2014), Colson G. (Liu et al, 2018), Haas R. (Haas et al, 2011), Heshmati A. (Abolhosseini \& Heshmati, 2014), Jacobs D. (Jacobs \& Sovacool, 2012), Liu S. (Liu et al, 2018), Maissner F. (Maissner \& Ukerdt, 2010), Panzer C. (Haas et al., 2011), Ukerdt F. (Maissner \& Ukerdt, 2010) and others) and domestic scientists (Bashynska Y. (Bashynska, 2015), Diachuk O. (Diachuk et al, 2017), Kurbatova T. (Kurbatova et al, 2014; Kurbatova \& Khlyap, 2015), Liutak O. (Liutak et al, 2017), Prokip A. (Prokip et al, 2015), Savosh L. (Liutak et al, 2017), Trypolska G. (Diachuk et al, 2017) and others) are devoted to the problems of RE development. The overwhelming majority of scientists consider theoretical and applied problems of the development of RE in the business sector, while the issues of managing "green" energy capacities deployment in the household segment are investigated fragmentarily. Given the fact that in recent years the Ukrainian population had the opportunity to become a full-fledged participant in the RE market, there is a necessity for a more detailed study of the problems and prospects for the development of this "green" energy sector as well as for substantiation of ways of public economic support of households in implementation of RE projects.

The aim of the article is to study the current state of innovative management of "green" energy development in the private sector of Ukraine, taking into consideration the existing mechanisms of economic stimulation, and justifying on this basis the expediency of strengthening the public financial and credit support of RE projects for the population.

Research results. Development of the private sector of RE in Ukraine. Despite the volatile economic situation of previous years and high inflation in the country, which represented unfavourable conditions for RE development, this industry has remained promising and relevant. For the last 5 years (2014-2018), the installed capacity of objects on the RES has increased by almost 1.79 times: from 967 MW in 2014 to $1,733 \mathrm{MW}$ in the second quarter of 2018 (Table 1) (SAEEESU, 2018).

This sector is becoming more and more attractive for small and medium-sized players in the market, first of all, because of stable feed-in tariffs, guaranteed by the state, which ensure investors' confidence in the return of their funds. Since June 2015, the right to produce and sell electricity from RES with feed-in tariffs has been granted to domestic households (The Verkhovna, 2015), which significantly expanded the range of market participants. As a result of this economic leverage, private "green" power generation grew almost 47 times in the last 3 years: from $0.023 \%$ in 2015 to $1.08 \%$ in 2017 . 
I. Sotnyk, I. Shvets, L. Momotiuk, Y. Chortok. Management of Renewable Energy Innovative Development in Ukrainian Households: Problems of Financial Support

Table 1 - Installed capacity of Ukrainian RE objects working under the feed-in tariff in 2014-2018, MWt

\begin{tabular}{|l|c|c|c|c|c|}
\hline \multirow{2}{*}{ Type of RE object } & \multicolumn{5}{c|}{ Year } \\
\cline { 2 - 6 } & 2014 & 2015 & 2016 & 2017 & 2018 (II Quarter) \\
\hline Solar electric stations & 411 & 432 & 531 & 742 & 948 \\
\hline Solar electric stations of households & 0.1 & 2 & 17 & 51 & 89 \\
\hline Wind electric stations & 426 & 426 & 438 & 465 & 515 \\
\hline Small hydroelectric stations & 80 & 87 & 90 & 95 & 96 \\
\hline Biomass & 15 & 17 & 20 & 34 & 41 \\
\hline Biogas & 35 & 35 & 39 & 39 & 44 \\
\hline
\end{tabular}

Sources: SAEEESU, 2018

At the same time, in absolute terms, the volume of electricity generated by solar power facilities of private households increased from 0.41 million $\mathrm{kW}$ in 2015 to 22.659 million $\mathrm{kW}$ in 2017. In 2017, the generation of electricity by the private sector at solar power plants (SPP) was added by electricity generation made by 4 private wind power plants with installed capacity of $0.032 \mathrm{MW}$, which generating $1,149 \mathrm{~kW}$ (Table 2). The growth of electricity during 2015 - the first half of 2018 was mainly due to an increase in the number of SPP in households. In 2015, there were 244 units with installed capacity of 2.2 $\mathrm{MW}$, and already in $2017-3,010$ installations with capacities of $51 \mathrm{MW}$. By the end of the second quarter of 2018, the number of SPP in households has increased to 4,660 , and installed power capacity - up to 89 MW (NCSREPU, 2018; NCSREPU, 2018a; SAEEESU, 2018; SAEEESU, 2018a).

Table 2 - The main indicators of RE development in the household sector of Ukraine in 2015-2018

\begin{tabular}{|l|c|c|c|c|c|}
\hline \multirow{2}{*}{ Indicator } & 2015 & 2016 & \multicolumn{2}{|c|}{2017} & 2018 (II Quarter) \\
\cline { 2 - 6 } & $\begin{array}{c}\text { solar } \\
\text { energy }\end{array}$ & $\begin{array}{c}\text { solar } \\
\text { energy }\end{array}$ & $\begin{array}{c}\text { solar } \\
\text { energy }\end{array}$ & $\begin{array}{c}\text { wind } \\
\text { energy }\end{array}$ & solar energy \\
\hline Number of generating units, pcs & 244 & 1,109 & 3,010 & 4 & 4,660 \\
\hline Installed capacity, MW & 2 & 17 & 51 & 0.032 & 89 \\
\hline Volume of electricity produced, million $\mathrm{kWh}$ & 0.410 & 4.246 & 22.659 & 0.001 & no data \\
\hline
\end{tabular}

Sources: SAEEESU, 2018; SAEEESU, 2018a

At the same time, in spite of the dynamic development of private objects in RES, the share of households in the production of "green" electricity at the state level remains very scarce. In the solar energy sector, this figure is somewhat better $-3.17 \%$ in 2017 with an increase of 55.3 times over the period 2015-2017 (NCSREPU, 2018). However, such growth rate of the industry is not enough for its significant contribution to the achievement of the planned indicators of RE development on a countrywide scale. This suggests that feed-in tariffs should be backed up by other instruments of public economic support.

Mechanisms of economic stimulation of RE development. Mechanisms for stimulating RE objects deployment are a certain sequence of actions to implement the necessary means to improve RE industry status. In the countries of the European Union, the following types of support for the deployment of "green" energy in the private and business sectors are distinguished:

- direct incentives - financial incentives for RE manufacturers, implemented through the usage of certain economic mechanisms (preferential tariffs and premiums, "green" certificates, tender schemes, investment grants, tax and customs incentives, subsidies, bonuses, etc.);

- indirect stimulation - encouraging the usage of RES directly by reducing the attractiveness of fossil energy resources through the introduction of environmental taxes, $\mathrm{CO}_{2}$ tax and others; 
- voluntary programs based on the willingness of consumers to pay high prices for energy generated with RES because of concern for the state of the environment in order to maintain the stability of the situation in the long term. Such programs include programs and charitable projects aimed at the accumulation of voluntary donations (Kurbatova et al, 2014; Kurbatova \& Khlyap, 2015).

The main elements of a comprehensive mechanism of state incentives for the development of "green" energy are the regulatory, organizational and economic, information and communicative, fiscal and tax mechanisms, and so on. At the same time, each individual element of public stimulation of RE's development is a combination of principles, forms, methods, tools and incentives (Hens et al, 2018).

Ukraine also introduced a number of motivational tools to support the deployment of RES capacities, namely (CMU, 2014):

- reduction of land tax for RE enterprises;

- exemption from taxation of: (1) profit from the main activity of companies in the energy sector that produce electricity from RES; (2) profit of biofuel producers from biofuel sales; (3) profit of enterprises derived from the simultaneous production of electricity and thermal energy and / or the production of thermal energy with the use of biological fuels; (4) profits of manufacturers of machinery and equipment for the production and reconstruction of technical and transport facilities consuming biological fuels;

- exemption from the imposition of value-added tax on operations involving the import into the customs territory of Ukraine of equipment that operates at RES, equipment and materials for the production of alternative fuels or for energy generation from RES, as well as exemption from payment of import duties of the mentioned equipment and materials;

- establishment of the feed-in tariff for the purchase of electricity generated from alternative energy sources at power stations (except for blast furnace and coke gases, and with the usage of hydropower produced only by micro, mini and small hydroelectric power stations) (The Verkhovna, 2017);

- establishment of an allowance to the feed-in tariff for the use of equipment of Ukrainian manufacture in "green" energy generation process (The Verkhovna, 2018).

However, the vast majority of these leverages are only applicable to business entities, which significantly reduces the attractiveness of investing in $\mathrm{RE}$ development for households. As noted above, for the private energy sector, the main stimulus tool is the feed-in tariffs (currently 2.13-3.36 times higher than tariffs for electricity produced from traditional energy sources), which extends to electricity generated from solar and/or wind energy by power plants of private households, the installed capacity of which does not exceed $30 \mathrm{~kW}$. At the same time, the state guarantees the purchase of electricity produced by such objects in the amount that exceeds the monthly electricity consumption by these private households (The Verkhovna, 2018). In addition, for the private sector, a simplified procedure for putting into operation of new "green" power facilities is established.

The obligation to purchase generated "green" electricity and the minimum bureaucratic procedures for deploying private capacities on RES, along with attractive feed-in tariffs, definitely motivate Ukrainian household owners to implement new projects. However, this motivation is not sufficient, since the main problem for this RE segment is the lack of available financial resources from the population that can be invested in the industry. Large capital investments in RES require households to search for sources of funding, the cost of which may be excessive. This is one of the main arguments in favor of further expanding the public financial support for RE in the country, taking into consideration that availability of credit resources is an important factor in the eco-innovation and energy-efficient development of the national economy, an integral part of which is the development of the RE (Kubatko, 2016; Sinevičienè et al, 2017).

Substantiation of economic expediency of credit resources attraction in projects for construction of private objects at RES. Low incomes of Ukrainian households make it necessary for them to apply for credit resources to banking institutions for the implementation of projects in the field of RE. However, 
interest rates of loans are usually relatively high. In addition, their receipt requires the implementation of a number of additional conditions regarding the timing of lending, the percentage of their own contribution, the amount of credit, etc. As a result, payback periods for RE projects are increasing and households' revenues are falling from their implementation, demotivating the population to install "green" energy facilities. To substantiate the economic feasibility of attracting credit resources to private RE projects and the necessity for public financial support of the industry, let consider the situation on the example of a typical domestic household with a roofing SPP.

The investigated private household is located in the north-east of Ukraine, in Sumy and has a functioning roofing SPP with an installed capacity of $10 \mathrm{~kW}$, put into operation in July 2017. The power consumption limit is $10 \mathrm{~kW}$. The electricity generated by roofing SPP, minus its volumes, consumed by the household for its own needs, enter the general electricity grid. At the end of the second quarter of 2018 the income of the household from the sale of such electricity at the current feed-in tariff (the coefficient of the tariff is 3,36 ) (Sumyoblenergo, 2018) minus taxes (value added tax, income tax and military duty) was $I=4.76 \mathrm{UAH} / \mathrm{kWh}(\$ 0.182)$. The dynamics of "green" electricity generation and consumption by the household is given in Table. 3 .

Table 3 - Indicators of the household electricity generation and consumption by months of the year

\begin{tabular}{|l|c|c|c|c|}
\hline Month & $\begin{array}{c}\text { Generation of } \\
\text { electricity, kWh }\end{array}$ & $\begin{array}{c}\text { Average electricity } \\
\text { consumption, kWh }\end{array}$ & $\begin{array}{c}\text { The volume of "green" } \\
\text { electricity sale, kWh }\end{array}$ & $\begin{array}{c}\text { Income from sale of } \\
\text { "green" electricity, } \\
\text { UAH/\$ }\end{array}$ \\
\hline \multicolumn{1}{|c|}{$(1)$} & $(2)$ & $(3)$ & $(4)=(2)-(3)$ & $(5)=(4) \times /$ \\
\hline January & 61 & 170 & 0 & 0 \\
\hline February & 128 & 170 & 98 & 0 \\
\hline March & 268 & 170 & 1,350 & $6,427.69 / 245.43$ \\
\hline April & 1,520 & 170 & 1,290 & $6,142.01 / 234.52$ \\
\hline May & 1,420 & 130 & 1,285 & $6,118.21 / 233.62$ \\
\hline June & 1,415 & 130 & 1,006 & $4,789.82 / 182.89$ \\
\hline July & 1,136 & 130 & 1,306 & $6,218.19 / 237.43$ \\
\hline August & 1,436 & 130 & 957 & $4,556.52 / 173.98$ \\
\hline September & 1,127 & 170 & 173 & $823.70 / 31.45$ \\
\hline October & 343 & 170 & 0 & 0 \\
\hline November & 132 & 170 & 0 & 0 \\
\hline December & 54 & 170 & 7,465 & $35,542.73 / 1,357.15$ \\
\hline Total for the year & 9,040 & 1,880 & & 0 \\
\hline
\end{tabular}

Sources: empirical data

The initial capital investments in the SPP construction amounted to UAH 314,270 (\$12,000). In addition, the household once paid to the local electric company 9,100 UAH (\$347.47) for additionally connected power of $7 \mathrm{~kW}(7 \mathrm{~kW} \times 1300 \mathrm{UAH} / \mathrm{kW})$. Thus, the total capital expenditures for the RE project amounted to UAH 323,370 (\$12,347.47) with an annual income from the sale of "green" electricity at UAH $35,542.73$ (\$1357.15). According to the current legislation, the validity of the feed-in tariff for an RE object is 10 years. The normative term of solar cells use is 25 years. Taking into consideration these data, the project is profitable, since the estimated simple payback period of the SPP will be $323,370 / 35,542.73=9.1$ years. The use of this indicator may be somewhat justified for carrying out preliminary calculations if the household invests in the project own funds. However, if the investment 
project involves credit resources, it is necessary to calculate a discounted payback period that takes into account their value.

Today, only two Ukrainian banks offer individuals special loans for realization RE projects, first of all, for the construction of SPP, namely Ukrhazbank and Oschadbank (Oschadbank, 2018; Ukrgasbank, 2018). Based on their loan conditions, we will substantiate the economic feasibility of attracting bank credit resources for the implementation of an investment project on the construction of SPP in the investigated household. For this purpose, we will calculate the net current value of the project and discounted payback period (Blank, 2001) as the main criteria for obtaining bank loans, along with the fact that the life cycle of the project is 25 years (Table 4). It will be taken into account that household incomes from selling "green" electricity outside the feed-in tariff period will be reduced by 3.36 times (see Table 4), and when calculating project costs, only received credit resources will be taken into account.

Table 4 - Input conditions for calculating the economic efficiency of the investment project for the SPP construction

\begin{tabular}{|l|c|}
\hline \multicolumn{1}{|c|}{ Indicator } & Indicator value \\
\hline Normative term of SPP use, years & 25 \\
\hline Total capital expenditures at the beginning of the project, UAH/\$ & $32,3370 / 12,347.47$ \\
\hline $\begin{array}{l}\text { Annual income from the sale of "green" electricity by the household during the feed- } \\
\text { in tariff term (10 years), UAH/\$ }\end{array}$ & $35,542.73 / 1,357.15$ \\
\hline $\begin{array}{l}\text { Annual income from the sale of "green" electricity by the household beyond the feed- } \\
\text { in tariff term (15 years), UAH/\$ }\end{array}$ & $10,578.19 / 403.91$ \\
\hline
\end{tabular}

Sources: compiled by the authors'

Ukrhazbank offers loans in the national currency to the population for the SPP construction in two major programs: (1) the loan program of Ukrhazbank and (2) the loan program of Ukrhazbank "EcoEnergy", implemented by the bank in conjunction with business partners that produce and supply SPP equipment (Table. 5).

Table 5 - Credit programs of banks for RE projects realization by households

\begin{tabular}{|c|c|c|c|c|}
\hline $\begin{array}{c}\text { Possible loan } \\
\text { amount }\end{array}$ & Lending period & $\begin{array}{l}\text { Maximum loan amount,\% of cost } \\
\text { of purchasing and installing SPP } \\
\text { (including value added tax) }\end{array}$ & $\begin{array}{l}\text { Interest rate on } \\
\text { a loan in UAH,\% }\end{array}$ & $\begin{array}{l}\text { Additional } \\
\text { one-time } \\
\text { payments }\end{array}$ \\
\hline 1 & 2 & 3 & 4 & 5 \\
\hline \multicolumn{5}{|c|}{ The loan program of Ukrhazbank } \\
\hline $\begin{array}{c}\text { from } 1,000 \text { to } \\
1 \text { million } \\
\text { UAH/ } \$ 38- \\
38,183 \\
\end{array}$ & from 1 to 5 years & 85 & 24.5 & $\begin{array}{l}4 \% \text { of the } \\
\text { loan amount + } \\
100 \text { UAH }\end{array}$ \\
\hline \multicolumn{5}{|c|}{ The loan program of Ukrhazbank "Eco-Energy" } \\
\hline \multirow{9}{*}{$\begin{array}{l}\text { from } 1,000 \text { to } \\
1 \text { million } \\
\text { UAH/ } \$ 38- \\
38,183\end{array}$} & \multirow{3}{*}{1 year (inclusive) } & $70.01-85$ & $0.001-6.99$ & \multirow{9}{*}{ - } \\
\hline & & $50.01-70$ & $0.001-4.99$ & \\
\hline & & 50 or less & 0.001 & \\
\hline & \multirow{3}{*}{$\begin{array}{l}\text { from } 1 \text { year }(+2 \\
\text { days) to } 2 \text { years } \\
\text { (inclusive) } \\
\end{array}$} & $70.01-85$ & $0.001-14.99$ & \\
\hline & & $50.01-70$ & $0.001-12.99$ & \\
\hline & & 50 or less & $0.001-9.99$ & \\
\hline & \multirow{3}{*}{$\begin{array}{c}\text { from } 2 \text { years }(+2 \\
\text { days) to } 3 \text { years } \\
\text { (inclusive) }\end{array}$} & $70.01-85$ & $4.99-16.99$ & \\
\hline & & $50.01-70$ & $0.001-16.49$ & \\
\hline & & 50 or less & $0.001-13.99$ & \\
\hline
\end{tabular}


I. Sotnyk, I. Shvets, L. Momotiuk, Y. Chortok. Management of Renewable Energy Innovative Development in Ukrainian Households: Problems of Financial Support

Table 5

\begin{tabular}{|c|c|c|c|c|}
\hline 1 & 2 & 3 & 4 & 5 \\
\hline \multicolumn{5}{|c|}{ The loan program of Oschadbank "Green Energy" } \\
\hline & \multirow{3}{*}{$\begin{array}{c}\text { from } 3 \text { years }(+2 \\
\text { days) to } 4 \text { years } \\
\text { (inclusive) }\end{array}$} & $70.01-85$ & $7.49-18.99$ & \\
\hline & & $50.01-70$ & $4.99-18.99$ & \\
\hline & & 50 or less & $0.001-15.99$ & \\
\hline & \multirow{3}{*}{$\begin{array}{l}\text { from } 4 \text { years }(+2 \\
\text { days) to } 5 \text { years } \\
\text { (inclusive) }\end{array}$} & $70.01-85$ & $9.99-19.99$ & \\
\hline & & $50.01-70$ & $6.99-18.99$ & \\
\hline & & 50 or less & $0.001-17.49$ & \\
\hline $\begin{array}{c}\text { to } 1 \text { million } \\
\text { UAH/ } \$ 38,183\end{array}$ & up to 6 years & 85 or less & 19.5 & $\begin{array}{c}2.99 \% \text { of the } \\
\text { loan amount + } \\
100 \text { UAH }\end{array}$ \\
\hline \multicolumn{5}{|c|}{ The loan program of American Savings Bank "Clean Energy" } \\
\hline \multirow{2}{*}{$\begin{array}{c}\text { from } \$ 1,500 \\
\text { to } \$ 70,000\end{array}$} & \multirow[b]{2}{*}{ up to 10 years } & \multirow[b]{2}{*}{ participating contractors only } & $\begin{array}{l}\text { in the first } 24 \\
\text { months: } 0.00 \text { (\$) }\end{array}$ & \multirow[b]{2}{*}{ - } \\
\hline & & & $\begin{array}{l}\text { in the following } \\
96 \text { months: } 7.99 \\
\text { (\$) }\end{array}$ & \\
\hline
\end{tabular}

Sources: American Savings Bank, 2018; Oschadbank, 2018; Ukrgasbank, 2018

Oschadbank also has its own loan program "Green Energy". In order to compare the conditions for obtaining loans for private RE projects, we have considered loan program of American Savings Bank "Clean Energy". The differences between loans for households provided by Ukrainian banks and the American bank are shorter terms and lending volumes as well as higher interest rates in Ukraine, which may be explained by a higher level of risk of lending to economic agents in the domestic economy. The results of calculating the net present value of the project and the discounted payback periods, depending on the conditions for granting bank loans, are given in Table. 6 . At the same time, the interest rate on the loan is assumed as the discount rate.

Table 6 - Results of calculations of net current value and discounted payback period under the project of construction of SPP with attraction of credit resources

\begin{tabular}{|c|c|c|c|c|c|c|}
\hline $\begin{array}{l}\text { Loan amount for the } \\
\text { SPP project taking into } \\
\text { account the maximum } \\
\text { possible amount of } \\
\text { credit and additional } \\
\text { one-time payments, } \\
\text { UAH } / \$\end{array}$ & $\begin{array}{l}\text { Amount of own } \\
\text { investment } \\
\text { contribution to the } \\
\text { SPP project, } \\
\text { UAH/\$ }\end{array}$ & $\begin{array}{c}\text { Lending } \\
\text { period, years }\end{array}$ & $\begin{array}{l}\text { Maximum loan } \\
\text { amount, \% of cost } \\
\text { of purchasing and } \\
\text { installing SPP } \\
\text { (including value } \\
\text { added tax) }\end{array}$ & $\begin{array}{c}\text { Interest rate } \\
\text { on the loan, } \\
\%\end{array}$ & $\begin{array}{l}\text { Net current value } \\
\text { of the project } \\
\text { calculated on the } \\
\text { basis of credit } \\
\text { resources, UAH/\$ }\end{array}$ & $\begin{array}{l}\text { Discounted } \\
\text { payback period } \\
\text { of credit } \\
\text { resources, } \\
\text { years }\end{array}$ \\
\hline 1 & 2 & 3 & 4 & 5 & 6 & 7 \\
\hline \multicolumn{7}{|c|}{ The loan program of Ukrhazbank } \\
\hline $\begin{array}{c}285,959.08 / \\
10,918.98\end{array}$ & $\begin{array}{c}48,505.50 / \\
1,852.12\end{array}$ & 5 & 85 & 24.5 & $\begin{array}{c}-152,455.45 / \\
-5,821.32\end{array}$ & $\begin{array}{c}\text { more than } 25 \\
\text { years }\end{array}$ \\
\hline \multicolumn{7}{|c|}{ The loan program of Ukrhazbank "Eco-Energy" } \\
\hline $\begin{array}{c}274,864.50 / \\
10,495.35\end{array}$ & $\begin{array}{c}48,505.50 / \\
1,852.12\end{array}$ & \multirow{2}{*}{1} & 85 & $0.001-6.99$ & $\begin{array}{c}239,187.60 / \\
9,133.07- \\
23,942.03 / \\
914.20 \\
\end{array}$ & $7.73-15.85$ \\
\hline $\begin{array}{c}226,359.00 / \\
8,643.23\end{array}$ & $\begin{array}{c}97,011.00 / \\
3,704.24\end{array}$ & & 70 & $0.001-4.99$ & $\begin{array}{c}287,693.10 / \\
10,985.19- \\
115,742.20 / \\
4,419.47\end{array}$ & $6.37-7.85$ \\
\hline
\end{tabular}


I. Sotnyk, I. Shvets, L. Momotiuk, Y. Chortok. Management of Renewable Energy Innovative Development in Ukrainian Households: Problems of Financial Support

Table 6

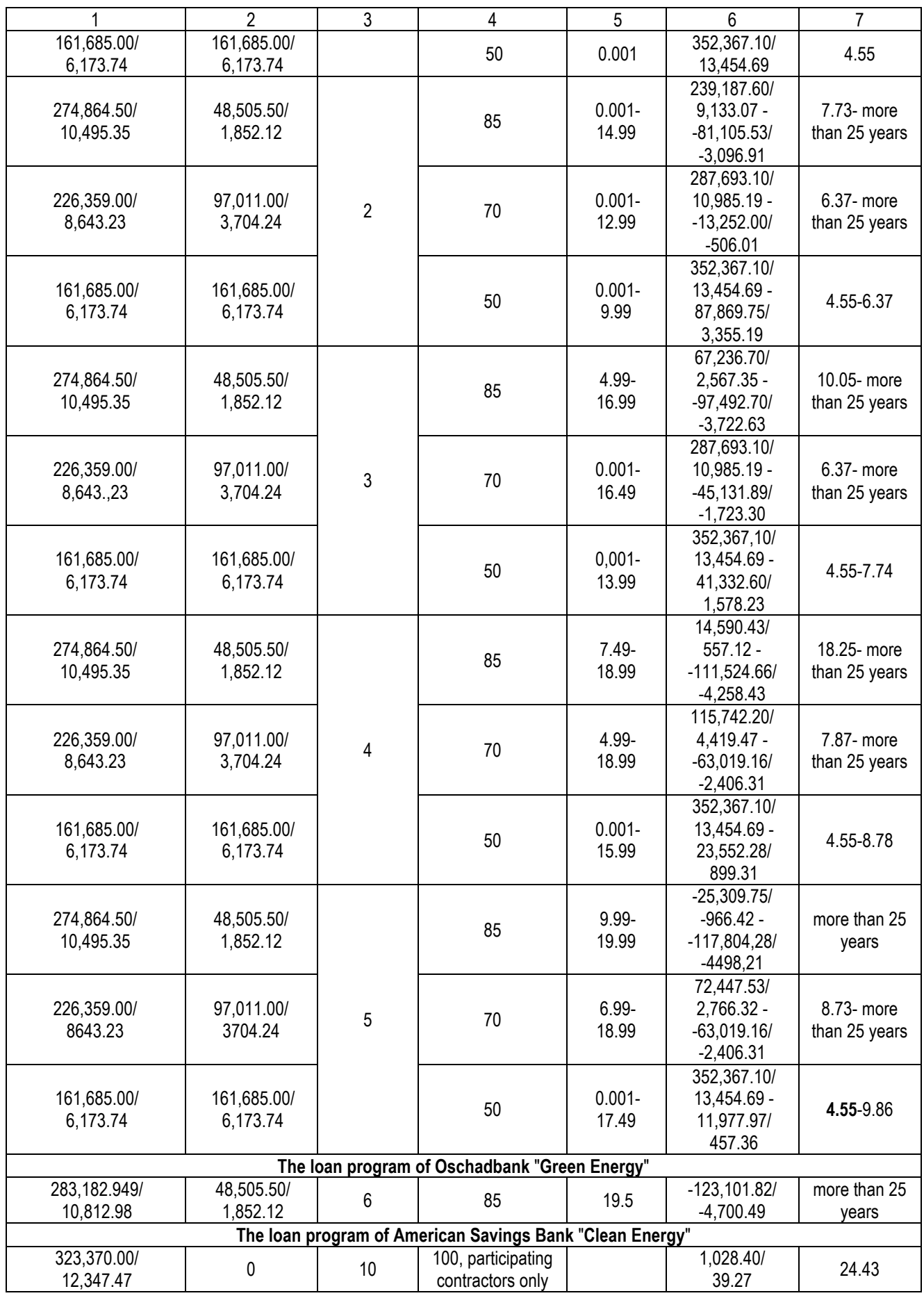


I. Sotnyk, I. Shvets, L. Momotiuk, Y. Chortok. Management of Renewable Energy Innovative Development in Ukrainian Households: Problems of Financial Support

\begin{tabular}{|c|c|c|c|c|c|c|}
\hline 1 & 2 & 3 & 4 & 5 & 6 & 7 \\
\hline $\begin{array}{c}274,864.50 / \\
10,495.35 \\
\end{array}$ & $\begin{array}{c}48505.50 / \\
1852.12 \\
\end{array}$ & & $\begin{array}{l}\text { 85, participating } \\
\text { contractors only }\end{array}$ & $\begin{array}{l}\text { in the first } \\
24 \text { months: }\end{array}$ & $\begin{array}{c}49,533.90 / \\
1,891.39 \\
\end{array}$ & 9.9 \\
\hline $\begin{array}{c}226,359.00 / \\
8,643.23 \\
\end{array}$ & $\begin{array}{c}97,011.00 / \\
3,704.24 \\
\end{array}$ & & $\begin{array}{l}70, \text { participating } \\
\text { contractors only }\end{array}$ & $\begin{array}{l}0.00(\$) \text { and } \\
\text { in the }\end{array}$ & $\begin{array}{c}98,039.40 / \\
3,743.51 \\
\end{array}$ & 7.6 \\
\hline $\begin{array}{c}161,685.00 / \\
6,173.74\end{array}$ & $\begin{array}{c}161,685.00 / \\
6,173.74\end{array}$ & & $\begin{array}{l}50, \text { participating } \\
\text { contractors only }\end{array}$ & $\begin{array}{l}\text { following } 96 \\
\text { months: } 7.99 \\
\text { (\$) }\end{array}$ & $\begin{array}{c}162,713.40 / \\
6,213.00\end{array}$ & 4.9 \\
\hline
\end{tabular}

Sources: compiled by the authors'

Based on the results of the calculations presented in Table 6, it should be noted that the target loans provided by Ukrainian banks today do not allow their potential recipient to repay loans at the expense of household income from the feed-in tariff. Payback periods of loans far exceed the terms of their provision. The only acceptable option is lending within the framework of the Ukrhazbank "Eco-Energy" program for 5 years in the amount of $50 \%$ of the total investment, which implies the application of a preferential credit rate of $0,001 \%$. The search for the rest of the required $50 \%$ of investments and the issue of their payback is a personal problem of the household. Considering the loan program of American Savings Bank "Clean Energy", within a 10-year lending period, acceptable options are to attract credit resources of $85 \%$ or less of the amount of the required investment, that is, if at least $15 \%$ of their own contribution. Thus, clients of the American bank have more favourable conditions for the implementation of RE projects. In general, when assessing the internal rate of return (Blank, 2001) of the SPP project, the full payback of $100 \%$ of the investment, within the project life cycle, is provided at a discount rate of $5,798 \%$. Consequently, this benchmark should become a decisive factor in the formation of governmental supportive mechanisms for preferential lending to the population for their RE projects implementation.

Conclusions. Taking into consideration the results of estimating the efficiency of attracting credit resources by households for the RE objects construction, the current credit policy of domestic banks in this area does not justify itself. Excessive lending rates keep the population from investing in RE's development. In this regard, in the unstable economic conditions of Ukraine and the relatively high risks of implementing RE projects by households, powerful state financial support that can provide cheap loan resources to each Ukrainian family is crucial, as well as effective cooperation between stakeholders of public, financial and real sectors of the economy. In our opinion, in this context, it is expedient to establish privileged interest rates, guaranteed by the state, for loans in the sphere of RE. At the same time, attractive levels of the feed-in tariff for the population should be maintained, as well as other stimulating economic instruments for this group of economic entities. For example, it could be tax privileges on individuals' incomes derived from the sale of "green" electricity, which would increase the profitability of RE projects in the private sector. Another direction is the state support for the development of RE technologies, which will in the future provide a cheaper price for equipment for SPP and other objects at the RES, making its own production of "green" electricity more accessible to every Ukrainian.

Prospects for further research. It should be noted that the development of RE in the household sector in perspective may lead to an increase in electricity prices in the state. This is explained by the fact that the feed-in tariffs are now offset by increasing average prices for electricity generated from both traditional and RES. Consequently, the further expansion of the RE sector in Ukraine, while maintaining relatively high feed-in tariffs, may cause social problems of income dispersion through the generation of "green" electricity. Therefore, an important issue for further research is the study of the possibilities for stimulating and supporting the processes of cheapening "green" technologies and ensuring equal access of households to investments in RE. 
Funding. The publication contains the results of research carried out within the framework of research works of the Ministry of Education and Science of Ukraine "Organizational and economic mechanisms for stimulating renewable energy development in Ukraine" (0117U002254), "System model of efficiency management and forecasting of electricity use" (0118U003583) and "Corporate social and environmental responsibility for sustainable development: stakeholders partnership in the real, financial and public sectors of the economy" (0117U003933).

\section{References}

Abolhosseini, S., \& Heshmati, A. (2014). Main support mechanisms to finance renewable energy development. Retrieved from http://ftp.iza.org/dp8182.pdf.

American Savings Bank (2018). Consumer loan interest rates. Retrieved from https://www.asbhawaii.com/files/documents/rates/LoansAndLinesRatesTables.pdf?dt=20181010105758.

Bashynska, Y. (2015). Why is it reasonable to invest in renewable energy in Ukraine? Baltic Journal of Economic Studies, 1: 17-23, Retrieved from https://cyberleninka.ru/article/v/why-is-it-reasonable-to-invest-in-renewable-energy-in-ukraine.

Blank, Y. A. (2001). Fundamentals of investment management: (Vols. 1-2): Kyiv, Nyka-Tsentr (in Russian).

CMU (2014). National renewable energy action plan for the period up to 2020: the decree of the Cabinet of Ministers of Ukraine (CMU) No. 902-p, 01.10.2014. Retrieved from http://zakon5.rada.gov.ua/laws/show/902-2014-\%D1\%80. (in Ukrainian).

CMU (2017). Energy strategy of Ukraine for the period up to 2035 "Safety, energy efficiency, competitiveness": approved by decree of the Cabinet of Ministers of Ukraine (CMU), No. 605-p, 18.08.2017. Retrieved from http://mpe.kmu.gov.ua/minugol/control/uk/doccatalog/list?currDir=50358. (in Ukrainian).

Diachuk O., Chepeliev, M., Podolets, R., Trypolska, G., et al. (2017). Transition of Ukraine to the Renewable Energy by 2050, Y. Oharenko, O. Aliieva (Eds), Heinrich Boell Foundation Regional Office in Ukraine. Kyiv, Publishing house "Art Book" Ltd.

Haas, R., Panzer, C., Resch, G. et al. (2011). A historical review of promotion strategies for electricity from renewable energy sources in EU countries. Renewable and Sustainable Energy Reviews, 15: 1003-1034.

Hens, L., Karintseva, O., Kharchenko, M., \& Matsenko, O. (2018). The state's structural policy innovations influenced by the ecological transformations. Marketing and Management of Innovations, 3: 290-301. http://doi.org/10.21272/mmi.2018.3-26.

Jacobs D., \& Sovacool B. (2012). Feed-in tariffs and other support mechanisms for solar PV promotion. Renewable Energy, 1 : 73-109.

Kubatko, O. (2016). Ecological innovations as a source of fluctuations of national economy energy efficient development. Marketing and Management of Innovations, 4: 365-376.

Kurbatova, T., \& Khlyap, H. (2015). State and economic prospects of developing potential of non-renewable and renewable energy resources in Ukraine. Renewable and Sustainable Energy Reviews, 52: 217-226.

Kurbatova, T., Sotnyk, I., \& Khlyap, H. (2014). Economical mechanisms for renewable energy stimulation in Ukraine. Renewable and Sustainable Energy Reviews, 31: 486-491.

Liu, S., Colson, G., Hao, N., \& Wetzstein, M. (2018). Toward an optimal household solar subsidy: a social-technical approach. Energy, 147: 377-387.

Liutak, O., Savosh, L., \& Baula, O. (2017). Features of the use of alternative energy sources in Ukraine and the world. Baltic Journal of Economic Studies, 3(4): 151-156, Retrieved from https://cyberleninka.ru/article/v/features-of-the-use-of-alternativeenergy-sources-in-ukraine-and-the-world.

Maissner, F., \& Ukerdt, F. (2010). Renewable energy development in Ukraine: potential, obstacles and recommendations for economic policy, BE Berlin Economics GmbH. Retrieved from http://www.kiew.diplo.de/contentblob/2968224/Daten/958255/studie_erneubarer_energie_download.pdf. (in Ukrainian).

Masharsky, A., Azarenkova, G., Oryekhova, K., \& Yavorsky, S. (2018). Anti-crisis financial management on energy enterprises as a precondition of innovative conversion of the energy industry: case of Ukraine. Marketing and Management of Innovations, 3 : 345-354, http://doi.org/10.21272/mmi.2018.3-31.

NCSREPU (2018). Report on results of the activities of the National Commission for State Regulation of Energy and Public Utilities (NCSREPU) in 2017: approved by decree of NCSREPU, No. 360, 23.03.2018. Retrieved from http://www.nerc.gov.ua/data/filearch/Catalog3/Richnyi_zvit_2017.pdf. (in Ukrainian).

NCSREPU (2018a). Letter of the National Commission for State Regulation of Energy and Public Utilities (NCSREPU) No. 3671/17.3.2/7-18 from 16.04.2018. (in Ukrainian).

Oschadbank (2018). Lending to "green energy" generation equipment. Retrieved from https://www.oschadbank.ua/ua/private/loans/kredituvannya-na-obladnannya-shcho-viroblya-zelenu-energ-yu/. (in Ukrainian). 
Prokip, A., Dudyuk, V., \& Kolisnyk R. (2015). Organisational and ecological and economic bases of renewable energy resources use; A. Prokip (Ed.). Lviv, ZUKC. (In Ukrainian).

SAEEESU (2018). Head of the State Agency on Energy Efficiency and Energy Saving of Ukraine (SAEEESU) - 4 years in office: achievements and plans for the development of energy efficiency and clean energy. Retrieved from http://saee.gov.ua/sites/default/files/PR_EE_RE_4_years_30_08_2018.pdf. (in Ukrainian).

SAEEESU (2018a). Letter of the State Agency on Energy Efficiency and Energy Saving of Ukraine (SAEEESU) No. 1901/17/31-18, 19.04.2018. (in Ukrainian).

Sinevičienè, L., Sotnyk, I., Kubatko, O., \& Lakstutiene, A. (2017). What makes countries to be energy efficient: case of Lithuania and Ukraine? Proceedings of the 2017 International Conference "Economic Science FOR Rural Development" No 45. Jelgava, LLU ESAF, 27-28 April 2017: 213-220.

Sumyoblenergo (2018). Information on "feed-in" tariff for electricity for private households. Retrieved from https://www.soe.com.ua/spozhivacham/fizichnim-osobam/zeleni-tarifi. (in Ukrainian).

The Verkhovna Rada of Ukraine (2015). On amendments to some laws of Ukraine on ensuring competitive conditions for the production of electricity from alternative energy sources: law of Ukraine No. 514-VIII, 04.06.2015. Retrieved from http://zakon.rada.gov.ua/laws/show/514-19. (in Ukrainian).

The Verkhovna Rada of Ukraine (2017). On electric power industry: law of Ukraine No. 575/97-BP, 16.10.1997 (updated 11.06.2017), Retrieved from http://zakon3.rada.gov.ua/laws/show/575/97-\%D0\%B2\%D1\%80. (in Ukrainian).

The Verkhovna Rada of Ukraine (2018). On electricity market: law of Ukraine No. 2019-VIII, 10.06.2018. Retrieved from http://zakon.rada.gov.ua/laws/show/2019-19. (in Ukrainian).

Ukrgasbank (2018). Credits for purchasing solar power plants and heat pumps. Retrieved from http://www.ukrgasbank.com/private/credits/eco_energy/. (in Ukrainian).

I. М. Сотник, д.е.н., професор, Сумський державний університет (Україна);

I. Б. Швець, д.е.н., професор, Донецький національний технічний університет (Україна);

л. $\boldsymbol{\epsilon . ~ М о м о т ю к , ~ д . е . н . , ~ п р о ф е с о р , ~ Н а ц і о н а л ь н а ~ а к а д е м і я ~ с т а т и с т и к и , ~ о б л і к у ~ т а ~ а у д и т у ~ ( У к р а і ̈ н а ) ; ~}$

ю. В. Чорток, к.е.н., доцент, Сумський державний університет (Україна).

Управління інноваційним розвитком відновлювальної енергетики у домогосподарствах України: проблеми фінансової підтримки

У статті досліджено сучасний стан управління розвитком «зеленої» енергетики у приватному секторі України. Проаналізовано механізми інноваційного розвитку та економічного стимулювання, які застосовуються в країнах

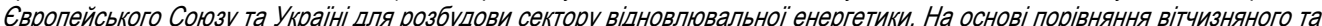
зарубіжного інструментарію виявлено обмеженість економічних і фінансових важелів, що використовуються на державному рівні в Україні для мотивації домогосподарств до впровадження проектів відновлювальної енергетики, а також відсутність налагодженої співпраці між стейкхолдерами реального, фінансового та державного секторів. Основним стимулом інноваційного розвитку відновлювальної енергетики для приватного сектору $\epsilon$ «зелений» тариф, а також спрощений порядок підключення «зелених» енергоустановок населення до загальної електромережі. Натомість для юридичних осіб додатково передбачено надбавки до «зеленого» тарифу, податкові та інші пільги. Зважаючи на низькі доходи домогосподарств України, авторами обірунтовано необхідність розширення кола застосовуваних інструментів економічного стимулювання в частині збільшення державної фінансово-кредитної підтримки проектів з будівництва приватних об'єктів на відновлювальних джерелах енергії. На підтвердження цієї тези у статті проведено аналіз економічної доцільності залучення кредитних ресурсів у проекти з будівництва об'єктів на відновлювальних джерелах енергії у секторі домогосподарств. Розрахунки показників чистої поточної вартості та дисконтованих строків окупності залучених у «зелені» проекти кредитних ресурсів за кредитними програмами українських та американського банків показали, що цільові кредити, які надаються українськими банками, за своїми умовами не дозволяють позичальнику повернути кошти за рахунок надходжень домогосподарства від «зеленого» тарифу. Строки окупності кредитів набагато перевищують терміни їх надання. Єдиним прийнятним варіантом $\epsilon$ кредитування в рамках програми Укргазбанку «Еко-енергія» на 5 років у сумі 50\% від початкових інвестиційних вкладень, що передбачає застосування пільгової кредитної ставки у 0,001\%. Розглядаючи програму “Clean Energy» американського банку American Savings Bank, в рамках 10-річного терміну кредитування прийнятними варіантами є залучення кредитних ресурсів на суму до 85\% від обсягів необхідних інвестицій, тобто за умови щонайменше 15\% власного внеску. Таким чином, клієнти американського банку мають більш сприятливі умови для впровадження проектів відновлювальної енергетики. 3 метою активізації інвестування населення в «зелені» енергооб'єки авторами обгрунтовано напрями посилення державноі фінансово-кредитної підтримки проектів «зеленої» енергетики у приватному секторі України.

Ключові слова: інноваційний розвиток, відновлювальна енергетика, домогосподарство, партнерство стейкхолдерів, кредитні ресурси, державна фінансова підтримка, управління.

Manuscript received: 04.11.2018

(C) The author(s) 2018. This article is published with open access at Sumy State University. 